Jarosław Różański ${ }^{1}$

Cardinal Stefan Wyszynski University, Warsaw, Poland

Faculty of Theology

\title{
Customary Gidar Marriage and Christian Tradition
}

The Gidar ${ }^{2}$ mainly inhabit the lands of the North Cameroon plateau, covered in the shrubbery of the savanna and small, isolated mountain ranges such as Hossere ${ }^{3}$. The greatest concentrations of the Gidar can be found in two cities of this region: Guider, seat of the Mayo Louti Prefecture, and Figuil. Other large clusters of the Gidar are found around the villages of Lam, Djougi, and Bidzar, on the banks of the Mayo Louti (from Mayo Loue all the way to Figuil), and around Sorawel ${ }^{4}$. There is only a rather modest amount of literature dedicated to the Gidar. The first extensive publication on the history of the region was the work of colonial administrator Jacques Lestringant ${ }^{5}$. The next important publication was authored by Chantal Collard, who conducted sociological research among the Gidar ${ }^{6}$. The

1 Jarosław Różański OMI prof. dr hab., professor and teacher at Cardinal Stefan Wyszynski University in Warsaw. Fields of research: missiology, missiological antropology, missions in Africa, cultures of Central Sudan, inculturation, e-mail: j.rozanski@uksaw.edu.pl. ORCID: 00000002-1678-2487.

2 The name "Gidar" most likely originates from French researchers, who spelled it "Guidar", after the name of the town "Guider", derived from the Gidar "g'dar" - "tireless", "restless". Other notations and names: "Guiddar", "Giddar", "Gidr", "Koudak" ("Kudak") in Daba and Giziga; "Marbun" in Fali.

${ }^{3}$ Hosseré - in Fulfulde, "mountain". "Hosseré" became part of the name of individual mountains.

${ }^{4}$ Currently their population in Cameroon is approximately 170,000, and approximately 15,000 living in the territory of Chad.

${ }^{5}$ Le pays de Guider au Cameroun. Essai d'histoire régionale, Versailles [s.e.] 1964.

${ }^{6}$ The fruit of her research was a doctoral dissertation submitted at the Paris X Nanterre University, entitled Organisation sociale des Guidar ou Baynawa (Cameroun septentrional), [ms] PST 39, 2021: 143-159. (C) The Author(s), Adam Mickiewicz University Press, 2021. Open Access article, distributed under the terms of the CC licence (BY-NC-ND, https://creativecommons.org/licenses/by-nc-nd/4.0/). 
most extensive study of the culture (especially religious culture) of the Gidar was a publication of Antoni Kurek, OMI, based on research of that region conducted from 1976 to $1977^{7}$. Also worthy of mention is the contribution of Polish missionaries to the development of literature in the Gidar language ${ }^{8}$.

In addition to the aforementioned literature, the author has also referred to his own field research, conducted in 1991-1993, 2001 and 2011, and to auxiliary literature.

In Cameroon we deal with three types of marriage: traditional, universally practiced marriage; civil marriage ${ }^{9}$, required by state law before entering into a religious marriage; and, finally, sacramental marriage. Most widespread is the traditional form of contracting marriage. This article will present this particular form, referring to Gidar traditions and also showing its similarities to, and differences from, the Christian tradition brought by the missionaries. It will also propose solutions which combine the two traditions.

\section{Gidar marriage according to traditional law}

Gidar rites of passage were celebrations of ties with the ancestral and territorial community, of the willingness to submit to its laws, orders, prohibitions, of and

Paris 1977. Cf. C. Collard, Du bon ordre des enfants. Etude sur la germanité guidar, "Anthropologie et Société" 4 (1980) 2, pp. 39-64; La société guidar du Nord-Cameroun. Compte rendu de mission, "L’homme - Revue Française d'Anthropologie" 11 (1971) 4, pp. 91-95; Les "noms-numéros" chez les Guidar, "L'homme - Revue Française d'Anthropologie" 13 (1973) 3, pp. 45-59.

7 Wierzenia i obrzędy Gidarów, ludu pótnocnokameruńskiego. Studium historyczno-hermeneutyczne, Warszawa 1988. It is also worth recalling here the thesis written by Loucien Boub, a Gidar seminarian at the Major Seminary in Maroua, entitled Mariage coutumier Guidar ou Kada et exigenes du mariage chrétien. Memoire de fin d'études de Grand Séminaire, [ms] Maroua 1991.

${ }^{8}$ The evangelization of the Gidar began in 1948. In 1970 the Polish Oblates of Mary Immaculate joined in this very actively. Cf. also worth of mention is the contribution of Polish missionaries to the development of literature in the Gidar language. A fruit of this was the publication of a Gidarlanguage grammar, first published in only a dozen or so copies on a mimeograph in Figuil (W. Kozioł, J. Manglé, Grammaire guidar, ms, Figuil 1993). That same year a new translation was begun in Lam of the Mass readings for Sundays and feast days. The outcome of this years-long work of the Polish missionaries and their co-workers was the publication of three liturgical lectionaries and an abbreviated Roman Missal as well as translations of the New Testament (Omanman Meleketeni. Nouveau Testament, guidar. Traduction, rédaction et révision linguistique: L. Bouba, T. Doulaneni, W. Kozioł, J. Maingle, M. Oumarou, J. Różański, K. Zielenda, Pelplin 2008) and the Psalter (Psaumes na Makada (gidar). Traduction, rédaction et révision linguistique: L. Bouba, T. Doulaneni, W. Kozioł, A. Madi, J. Maingle, B. Haman, M. Oumarou, J. Różański, K. Zielenda, Figuil-Varsovie 2015). The first professional grammar in the Gidar language came out in 2008. Its author was the linguist Professor Zygmunt Frajzyngier of the University of Colorado, USA (Z. Frajzyngier, A Grammar of Gidar, Frankfurt am Main 2008).

${ }^{9}$ Based on French law. 
respect for the value of this community and for all of its rules of life. Consequently, each rite was associated with the obtaining of relevant rights and the taking on of the obligations arising from them. This concerned birth, initiations, marriages, and funeral rites, by which a member of the community passed on to the members of his family abiding beyond the visible world. A characteristic feature of rites of passage was their multi-stage nature. They were not single acts but events long prepared and celebrated with suitable gestures, symbols-and words. The individual, successive stages of "taking a wife" consisted of the choice of a spouse, accepted by both families; an engagement period; an act by both families of acknowledgement of joining the young persons as one in marriage; the conveying of the bride to her husband's home; celebrating; and paying the matrimonial fee.

\section{Traditional conditions for marital consent}

Marriage among the Gidar as in marriage all over sub-Saharan Africa is not as a rule the decision of the young persons but of their parents or even of the elders of the clan ${ }^{10}$. It is after all a contract between two families (in the broad sense of the term), and therefore, the family has a significant influence over the choice of a spouse. Although in the present day there is a noticeable, steadily increasing, transition from marriage organized by the family to marriage based on personal consent, as a rule the old matrimonial principles are still in force, based on clan exogamy (marriage of related persons should be avoided) and ethnic endogamy (you must marry someone within your ethnic group) and territorial endogamy (generally, you marry someone from a specific area). A second notable tendency is a slow transition from polygyny to monogamy. Polygyny is however still present among the Gidar and throughout Africa in spite of some laws restricting it. A third trend also slowly coming around is a shift from joint ownership within a clan to individual inheritance.

Traditional Gidar marriage follows all-African and local trends and is more a covenant between two families than a union of two persons. Entering into such a covenant requires broader consent, and it is part of family policy. From then on (after the marriage takes place), the two clans will be joined by the gift of the woman (from her family to her spouse's). The marriage covenant is seen above all as a necessary means for extending the life of the clan: a woman belonging to one family bestows the gift of her fertility unto another family as her children will belong to the lineage of her husband. Since in the local religious tradition the givers of life

${ }^{10}$ A clan is a group of persons related by blood and descending from a real or theoretical common (most often legendary) ancestor, united by a sense of community from this origin and a common name. Cf. S. Szynkiewicz, Ród [in:] Stownik etnologiczny, ed. Z. Staszczak, Warszawa-Poznań, p. 321 . 
are primarily the ancestors, this passage of a woman-mother to another family must be lawful, i.e., in accordance with the will of the father and his family (including deceased ancestors) ${ }^{11}$.

In giving a woman to a family with whom there are friendly relations, compensation is expected in the form of a matrimonial fee. This payment is made to the bride's family. Fees consist of money, livestock, labor, etc. The marriage is not final until the last payment has been made.

\section{Obstacles preventing or dissolving marriage}

We can also find in the Gidar tradition obstacles which prevent or break up marriage. In the Gidar language the term for an obstacle to marriage is henzin.

The first obstacle to contracting marriage - and in the case of entering marriage unaware of this obstacle, of annulling it - is kinship. The rules of exogamy are restrictive and apply to all relatives of the whole family. Since clans are often large and may not necessarily all be living in the same territory, mistakes can occur. In such a case, the elders pass a sentence annulling the marriage and special purification rites are performed. Marriage is also prevented by certain close relationships, and also by ties resulting from the adoption of a child. Another obstacle dissolving-marriage is impotence of the husband (in Gidar terminology: gemen mement - "dead member")-for the primary task of marriage is to produce offspring. Moreover, according to tradition, a girl getting married should be a virgin (mbugbo). If this were not the case, it would be an obstacle to the marriage: the girl would return home to her parents covered in shame. Today, as a rule this is no longer treated as an obstacle to marriage ${ }^{12}$.

Infertility on the part of the woman (ndarzlay) could also lead to invalidation of the marriage. At the same time, as a rule it is the woman who is blamed if there are no children ${ }^{13}$. If a young married woman turns out to be infertile, the husband returns her to her father and his matrimonial fee is reimbursed. Another obstacle nullifying marriage was the spouse's not meeting all payments provided for in the already agreed-upon matrimonial fee to be paid to the bride's parents. The issue

${ }^{11}$ Cf. V. Mulago Gwa Cikala, Mariage traditionnel africain et mariage chrétien, Kinshasa 1991, pp. 13-15; J. Maquet, Mariage [in:] G. Balandier, J. Maquet, P. Alexandre, H. Balfet, G. Condominas, et al., Dictionnaire des civilisations africaines, Paris 1968, pp. 263-264; B. Bujo, Plea for change of models for marriage, Nairobi 2009, pp. 94-103; B. Kisembo, L. Magesa, A. Shorter, African Christian marriage, Nairobi 2015, pp. 202-213.

${ }^{12}$ Cf. L. Bouba, Mariage coutumier Guidar ou Kada et exigenes du mariage chrétien. Memoire de fin d'études de Grand Séminaire, pp. 31-36.

13 "Even a bird laughs" at such a woman, says the Giziga proverb (Ngwas hana, diyuw asingir angan), and the Tupuri saying explains that a man is always capable of begetting children, "a man produces offspring in the world even with a dry tree" (je twar bin koo de hegge). 
of seniority could also be a hindrance preventing marriage: tradition followed the principle that the eldest daughter would be the first to marry, after that her younger sisters, in order of age $\mathrm{e}^{14}$.

\section{Marriage forms}

There are four basic forms of Gidar marriages:

a) the multi-stage, full marriage rites, which end when the final payment of the matrimonial fee is remitted

b) marriage contracted before the final payment of the marriage fee has been made

c) marriage through abduction of the girl

d) widow inheritance under leviratic law.

Getting married does not require the presence of any religious leader, nor of any other person representing the community as a whole. It is above all else a contract between two clans.

Elaborate marriage rituals are, however, religious. These religious foundations come from the bond between the world of the living with the world of deceased ancestors, including the founding ancestor of the given tribe, clan, or lineage. The deceased ancestors continue to be involved in the daily events of family life, especially during sowing and harvesting, initiation and marriage. If the family is treated as a large chain whose living members form one group, family law has its roots in the religious and at the same time invisible world. Offerings made to ancestors at various stages of the multi-stage process of marriage attest to this. These are meant to procure their "blessing" to the marriage.

Despite the prevalence of polygamous marriage, many traditions emphasize the fact that only the marriage to a first wife is entitled to the full marriage ritual.

\section{The multi-stage, full marriage ritual}

The contracting of marriage is composed of several stages. The first of these is preparation for marriage, which can be divided into more remote (the search for marriage candidates) and immediate (the engagement itself, begun with a proposal; visiting the future in-laws) stages.

${ }^{14}$ Cf. L. Bouba, Mariage coutumier Guidar ou Kada et exigenes du mariage chrétien. Memoire de fin d'études de Grand Séminaire, pp. 36-38. The age [relationship] of sisters was indicated by their so-called "numeric" names. Each girl was given a name according to her birth order. This indicated her place in the family hierarchy. Cf. C. Collard, "Les noms-numéros" chez les Guidar, pp. 45-59. 
Further preparation for marriage includes the initiative of the future father of the family. One of the ways in which this is expressed is in the Gidar vocabulary, which for the term "get married" has only one phrase: ugum gulku, "take a woman". When the father of the marriage candidate and his older brothers accept a proposed candidate for his wife, the boy becomes agmuk gulku, "the one who has taken himself a woman". The parents of the girl have not yet expressed agreement to the marriage of their daughter. The boy then asks his chosen one, in the presence of her mother, whether she wants to be his wife. After she has consented, he turns to his future father-in-law. After his agreement - and the agreement of the elders of the clan - the first installment of the marriage fee is made over. Traditionally, this was a gift of millet, tobacco, and hens, treated as a type of a proposal. After paying this first installment, the parents of the affianced meet together. This is the final sign of agreement. Later the amount of the entire fee paid to the girl's father is determined. After receiving the consent of the girl's father, the young man becomes aratuk gulku, "the one who has found himself a woman".

The actual marriage ceremonies are called udaha among the Gidar. They consist of seven stages: ubassa, ubele, udama, ungla, uka, ute glo and upedde.

The verb ubassa means "to place a stone on something". It is a kind of security, and in the marriage rites it therefore means the same as "engaged".

The second stage - ubele - means "bringing the girl" to her in-laws' compound. This, however, does not give the young people the right to have intercourse. The bride-to-be gets acquainted with the family of her future husband, and the family in turn observes this candidate. Their assessment of the candidatefor-wife influences the amount of the subsequent installment of the matrimonial fee. The interval between ubassa and ubele can last even up to two years - it depends on the wealth of the groom (matrimonial fee installments). In the past udama, that is, hiding from the in-laws, was also practiced.

The next stage is $u k a$, "relocating" the girl to the boy's compound. The "setting up of the hearth", ute glo, then takes place there; this was the most important part of the marriage rites. Beside the hut the young wife places three stones which will be the hearth for her kitchen. An approved formula such as, "glo nok yanka! - here is your hearth!" is then repeated. From then on she is no longer a gorku, that is, a "girl", but a gulku, a "woman (wife)".

On the following day everyone would gather in the compound of the young husband for the upedde, the banquet after the wedding night ${ }^{15}$.

15 There is a more detailed description of Gidar marriage [in:] A. Kurek, Wierzenia i obrzędy Gidarów, ludu pótnocnokameruńskiego. Studium historyczno-hermeneutyczne, pp. 318-342; see also O.L. Draman, Symbolisme religieux dans l'ethnie Ngambay. Approche culturelle de la religion, [ms] Ottawa 1975, pp. 28-36. See also the list of marriage rites of 12 Paleonigrosudan tribes from the Central African Republic, Chad and northern Cameroon [in:] Enquete sur la coutume relative au mariage [in:] Rapport de stage de pastorale, Fort-Archambault, 20 juin-10 juillet 1971, Fort- 


\section{Incomplete marriage rites}

It can be called an incomplete marriage ritual when there are difficulties in paying the marriage fee. It sometimes happens that, in spite of preliminary arrangements, new financial demands are made of the son-in-law. The Gidar proverb says, "ariya nakat gulku agrakba - the marriage fee never comes to an end". Then the candidate for a wife may be "abducted". This, however, does oblige the husband to pay the entire fee, though at a later date.

Another form of marriage is what is known as "kidnapping" the girl. This happens when the young people (the boy and the girl) fall in love but for various reasons (such as the boy's family being too poor to pay the marriage fee) they cannot marry. The "kidnapping" usually takes place at night and is only possible with the agreement of the girl. It is she herself who leaves her parents' compound in secret and goes off to an agreed-upon meeting with her lover, or simply vanishes in other circumstances. As a rule, such marriages enjoy favor with the local community. However, "kidnappings" do not always work out well ${ }^{16}$.

\section{Leviratic law}

Yet another form of marriage is "inheriting the wife" and her children, after the death of a brother or close relative (leviratic law). This springs from many reasons, including the obligation to take care of the family of the deceased brother. But usually the widow is left free to choose a new husband. Among the Gidar, candidates were presented to the widow immediately after the funeral ceremonies brothers of the deceased with the intention of marrying her and accepting her children. Sometimes, other men belonging to the clan also present themselves. The widow herself makes the decision, handing the chosen one a calabash filled with beer. The one who receives it would take the widow and her children to his home. If she did not choose any of them but went to a man from another clan, this man would be obliged to pay a marriage guarantee to the eldest living brother who - according to the law - was the heir. ${ }^{17}$ In this case, the offspring born of the woman in this new marriage would legally belong to the deceased, and she would continue to be considered the wife of the deceased.

Leviratic law originated from and functions in a broad socio-cultural framework which includes kinship systems, family models, local societal organizations, and traditional beliefs.

Archambault 1971, pp. 44-50; M. Tagy, A. Yondo, Témoignage d'un foyer [in:] Rapport de stage de pastorale, Fort-Archambault, 20 juin-10 juillet 1971, Fort-Archambault 1971, pp. 59-64.

${ }^{16}$ Cf. J. Różański, W cieniu góry Lam, Gorzów Wielkopolski 1994, pp. 14-17.

17 Cf. K. Zielenda, Prastare prawo lewiratu, „Misyjne Drogi” (1994) 3, pp. 14-15. 
The levirate upholds and completes all existing references and arrangements, from maintaining the relationship between two clans and following up with the marriage contract and payment, to the relationship of the ancestors of the deceased by raising up progeny for him.

\section{The marriage fee}

Another important element upon entering into marriage was the marriage fee, which has already been mentioned several times, in Gidar ariya nakat gulku. Translated literally, this means "riches for a wife", or also "the price of a wife". Originally, the marriage fee was not understood by the Gidar as ariya ("riches", "price"). It was rather a symbolic compensation for giving over a woman to another clan; it was a sign of a covenant between the clans, a ritual proof of consecration in marriage and evidence of the resourcefulness of the groom-to-be. Without it, the relationship was seen as cohabitation, and the man had no authority in the family. The marriage fee was regarded as a sign of responsibility of the man for the woman. It guaranteed mutual respect between the spouses and constituted a separation of the wife from her family. It was also an expression of the recognition of the husband's family for that of the wife's. It guaranteed the wife's attachment to her husband and strengthened mutual fidelity between the spouses. It was only after payment of the marriage fee that the parents gave the young wife their blessing. In more recent times, however, these positive aspects have been receding further and further into the background and giving way to desires for wealth, a result of changes related to the emergence of money. The amount of the marriage fee gets higher every year and is the cause of many conflicts between clans $^{18}$.

\section{Christian marriage and local traditions}

Christianity, which has gradually been coming into northern Cameroon for over 70 years, brings with it a different view of marriage. From the very beginning, the tradition of the Church has treated marriage as a union between a man and a woman, based on a contract (covenant), expressed [by them] consciously and freely. This contract, when entered upon by baptized persons, has been raised to the dignity of a sacrament by Christ Our Lord. Its essential attributes are therefore unity and indissolubility, which in Christian marriage acquire a special strength

${ }^{18}$ Also writing on the topic of changes in how the marriage fee is treated by the Gidar is L. Bouba [in:] Mariage coutumier Guidar ou Kada et exigenes du mariage chrétien. Memoire de fin d'études de Grand Séminaire, pp. 23-24. 
by the power of the sacrament, "For as God of old made Himself present to His people through a covenant of love and fidelity, so now the Savior of men and the Spouse of the Church comes into the lives of married Christians through the sacrament of matrimony" 19 .

The sacramentality of Christian marriage has been a subject of the teaching of the Church from the very beginning, although no strict terminology has been developed.

The Church in northern Cameroon recognized traditional marriages contracted outside of baptism as valid and licit, provided that local principles, e.g., payment of a marriage fee, were taken into account. If either of the parties accepted baptism, the marriage became for him or her sacramental. If the other party also made the same decision later on, their union took on a sacramental character, without a need to renew the marriage vows. Controversy would, however, arise if attempts were made to contract a traditional marriage if one party was [already] baptized, or if both parties were baptized. These controversies mainly concerned the unity, indissolubility, and sacramentality of marriage.

\section{The issue of the unity of marriage}

An essential attribute of Christian marriage is its "unity;", which has its source in the will of God, expressed in the Book of Genesis and repeated by Jesus Christ, "[A] man leaves his father and mother and clings to his wife, and the two of them become one body" (Gen. 2:24). This expression, "the two of them become one body" means unity in marriage in the sense of monogamy, as well as in the sense of physical and spiritual unity. This unequivocally monogamous nature of Christian marriage stands in opposition to polygyny. Polygyny is respected by the country's law. In the past it was more associated with the economic and selfdefense requirements of clans; it was also treated as a sign of distinction for men and allowed for marriage contracts to be made with many clans. It was also often brought about by women's infertility, by the advancing age of a first wife, as a means to limit casual sexual relations, as a way of ensuring care for children, and so on. Along with [other] social changes, its nature and ambitions have also decidedly changed; wealth and vanity now take precedence over other motivations, especially in urban areas.

In many cases levirate law has also led to polygyny. This appeared in the Old Testament and was associated with patrilineal social structure based on endogamous tribes. In the case of a deceased brother having a wife, levirate marriage is

19 Second Vatican Ecumenical Council, Pastoral Constitution on the Church in the Moderne World Gaudium et Spes 48, https://www.vatican.va/archive/hist_councils/ii_vatican_council/documents/vat-ii_const_19651207_gaudium-et-spes_en.html [accessed 09.10.2021]. 
the same as polygynous marriage and so the same principles are applied to it as are applied to polygynous marriage.

\section{The issue of marriage indissolubility}

The indissolubility of marriage, resulting from its divine institution in the Book of Genesis (2:24), was unequivocally repeated by Jesus Christ with the words, "What God has joined together, no human being must separate" (Mt. 19:6) ${ }^{20}$. The Code of Canon Law of the Catholic Church, however, does recognize the existence of obstacles that can either prevent or dissolve marriage. Some of these overlap with traditional Gidar marriage law, as for example impotence on the part of the man. The prohibition of marriage between relatives only partially coincides, because kinship in the Gidar tradition is understood in a very broad sense. The Code of Canon Law, however, does not take into account other traditional obstacles that prevent or dissolve marriage, such as lack of virginity on the part of the bride, or the custom of marrying girls off according to their birth order in the family ${ }^{21}$. The indissolubility of marriage could also be influenced by lack of children, who were a de facto guarantee of permanence of marriage. The traditional Gidar family did not know childless marriage. A Gidar "son" (utun) became a "man" (zile), when he became a father; a "daughter" (wanke) became a "woman" (guluk), when she became a mother ${ }^{22}$. If it turned out that a young wife was infertile, the husband would return her to her father in exchange for a refund of the marriage fee.

Christian marriage is also decidedly opposed to dissolution of marriage because of failure of the new husband to make full payment of the marriage fee to his father-in-law. All the more so because - as has been mentioned - contemporary changes have led to a specific treating of the marriage fee as an important source of gaining wealth.

Local tradition respected also a man's dismissing his wife for other reasons, as well as the wife leaving the man. If this was the fault of the man, the wife would take the children to her own family and the marriage fee would also remain there. It if was the fault of the wife, the children would remain in the father's compound and he would demand a refund of the marriage fee.

${ }^{20}$ Scripture quotations are taken from the New American Bible, official translation for the United States Conference of Bishops, https://www.usccb.org/offices/new-american-bible/booksbible [accessed 09.10. 2021].

${ }^{21}$ Cf. The Code of Canon Law of the Catholic Church, canon n. 1083-1094. Code of Canon Law, Annotated, eds. E. Caparros, M. Theriault, J. Thorn, Montreal 1993.

${ }^{22}$ In the tradition of the Gidar, parenthood was reserved only to married people. Conceiving a child before the marriage rites, called conception in the father's compound, was treated as a curse for which the girl sometimes received the death penalty, and her child was also killed. 
The Christian concept of the indissolubility of marriage, lasting until the death of one of the spouses, is also opposed to the abovementioned levirate tradition. Levirate law stresses that the marriage contract endures even after the death of the man, since it is a contract between clans. Jesus, in answering the Sadducees' question about the fate of marriage after the [final] resurrection of the dead, notes that no one will then marry or be given in marriage, because marriage is strictly connected to earthly existence ${ }^{23}$. Moreover, it is questionable whether a living brother or another relative should be considered to be acting on behalf of someone who is deceased, in relation to marital duties. Acting on behalf of the deceased, such a substitute is not considered to be the new husband of the woman nor the father of the children of their union, which seriously violates the dignity, unrepeatability, and uniqueness of the human person.

\section{The issue of freedom (the will to get married)}

In treating marriage as the union of a man and a woman, Christianity emphasizes the necessity that the covenant between them be clearly and freely expressed. Sometimes in local marriages, the contract was in direct contradiction to freedom and the will to get married - especially in the case of child-brides - and thus violated the very foundations of validity.

The problem of free will in contracting marriage appeared in marriages arranged by the elders of the clan. Also in other cases, pressure from the parents (elders) causes problems with the question of voluntary marriage.

\section{The question of the form of marriage}

The sacramentality of marriage about which the Church speaks, cannot be separated from the marriage contract. If the contract is invalid, then so is the sacrament. For Christ gave marriage a supernatural character, but He did not define its form. Hence it belongs to the Church to define marriage forms.

In the Western Church a form has been developed over centuries based on Roman law: it is the consent of the spouses which decides [contracts] the marriage. In this regard the African bishops posed the question of whether the teaching and practice of the Church, limiting weddings (in the African context) to a single stage of marriage - the exchange of vows by the married couple - was a biblical and universal practice from the anthropological point of view, or was it rather a practice inspired solely by Roman law? ${ }^{24}$. This appears to be an important

${ }^{23}$ Cf. K. Wojtyła, Mitość i odpowiedzialność, Lublin 1986, p. 190.

${ }^{24}$ Cf. Symposium des Conférences épiscopales d'Afrique et de Madagascar, Vers l'indigénisation du rituel chrétien du mariage (Accra, 15 septembre 1976), "Documentation catholique" (1977) 1718 , pp. 360-361. 
question because, as Antoine Phillipe - a missionary to the Bambara and author of an extensive study of engagement and marriage - stated years ago: we often unconsciously live in an ethnocentric Church, sometimes connected with a no less real cultural imperialism ${ }^{25}$.

This manner of contracting marriage was in clear opposition to the local, extensive and multi-stage forms, which in addition emphasized the community dimension of marriage. Consent in traditional marriage was given over stages. The first of these was the consent of the clans on both sides; the second consent was that of the spouses themselves; the third and fourth, which confirmed the marriage, were the paying of the marriage fee and the birth of a child. The Christian way of getting married in church (the wedding ceremony) seemed like something incidental, insignificant, not in any way in line with tradition. Some Christians would end up by having two weddings so as to satisfy both local traditions and the requirements of the Church. But these were specific cases.

\section{The need for finding an inculturated form of contracting marriage}

The problem of finding paths of dialogue and solutions between the form of marriage required by the Church and the traditional forms of Sub-Saharan Africa (including Gidar) has been seen for many years as essential and urgent. This was encouraged by the attitude of John Paul II, who, keeping to his approach of respect and acceptance by the Church of every culture it encounters, at the beginning of the apostolic exhortation Familiaris Consortio, confirmed as something fundamental that, "God's plan for marriage and the family touches men and women in the concreteness of their daily existence in specific social and cultural situations". And he pointed out the fact that, "the Church ought to apply herself to understanding the situations within which marriage and the family are living today, in order to fulfill her task of serving" ${ }^{26}$. The question of attitude towards local marriage traditions also came up during a meeting of the Episcopal Conference of Africa and Madagascar which took place in 1981 in Yaoundé, Cameroon. At that time the bishops of Africa and Madagascar placed the issue of marriage among those that were the "deepest and most important" for Africans ${ }^{27}$. But despite numerous proposals, no general or continental norms were devel-

${ }^{25}$ Cf. A. Philippe, Le mariage. Droit canonique et coutumes africaines, Paris 1992, p. 501.

${ }^{26}$ Familiaris consortio 4, https://www.vatican.va/content/john-paul-ii/en/apost_exhortations/ documents/hf_jp-ii_exh_19811122_familiaris-consortio.html [accessed 10.20.2021].

${ }^{27}$ Recommendations for marriage and family in Africa, developed during the SCEAM general assembly in Yaoundé, June-July 1981. Cf. Symposium des Conférences Episcopales d'Afrique et de Madagascar, Justice, mariage et évangélisation en Afrique d'aujourd'hui, Yaoundé 1981, Accra 1982, pp. 13-16. See also J.C. Bouchard, La famille chrétienne dans le monde d'aujourd'hui. 
oped to reconcile the relationship between sacramental marriage and traditional unions. The problem remains unresolved and has often returned during sittings of the Synod of African Bishops. In proposal no. 35, the Synod fathers recommended that all questions related to marriage be analyzed from the theological, sacramental, liturgical, and canonical viewpoints; in particular with reference to cultural issues ${ }^{28}$.

\section{Traditional marriage values}

In the Gidar marriage process many values, both human and Christian, can be seen. These certainly include the encouragement to premarital chastity; fidelity and a strong disapproval of adultery; an emphasis on indissolubility, which is confirmed by many proverbs and traditions; the relationship between the spouses' families; solidarity; fertility, respect for life, bringing up of children, etc.

\section{Expanding the engagement and initial stages}

Looking at the multiple stages of Gidar marriage and its extensive preliminary forms (long-term and immediate preparation), it is possible to attempt to link Christian marriage and customary marriage. This can be done during traditional ceremonies, either by the presence of a priest or of those responsible for the Christian community. After the initial discernment, when the boy becomes an agmuk gulku, "one who has chosen himself a woman", young people can be accompanied by the Christian community, especially by those of their own age group. Subsequent rites can be combined with prayer and blessings, crowned with the ubassa rite, that is to say, the official engagement. This stage forms an important part of African heritage. Among the Gidar there are other - already mentioned - stages: ubele, udama i uggla. These stages are essential in order for the young people to be able to discover the values which marriage brings with it, to engage in dialogue together, to open their hearts, and also to take on new responsibilities: responsible parenthood, raising children, the apostolate, and being open to others. These stages are not associated with premarital sexual relations in either the

Compte-rendu du Synode des Évêques 1980 pour les communautés chrétiennes du Tchad, Moundou 1981.

${ }^{28}$ Synodus episcoporum. Coetus specialis pro Africa, Les 64 propositions [in:] Le Synode aficaine. Histoire et textes, ed. M. Cheza, Paris 1996, p. 256. This proposal is also recalled by John Paul II in the Post-Synodal Exhortation Ecclesia in Africa, saying that episcopal conferences in cooperation with Catholic universities and institutes should establish study commissions that will deal with issues concerning marriage primarily from the theological, sacramental, liturgical and legal perspective (EAfr 64). https://www.vatican.va/content/john-paul-ii/en/apost_exhortations/ documents/hf_jp-ii_exh_14091995_ecclesia-in-africa.html [accessed 10.10.2021]. 
Gidar or Christian traditions. Both traditions advocate that bodily union should take place only within marriage; moreover, Catholic tradition emphasizes that it should be a sacramental marriage. Chastity - as both a human and Christian virtue - is obligatory during the premarital period and is a preparation for the later, equally important virtue - fidelity.

Since the preliminary stages of Gidar marriage also have a community dimension, these traditions can be continued by proposing that the fiancé be accompanied, in addition to parents and friends, by those who are responsible for the local Christian communities. They can also be effectively supported by other Christian couples, who can strengthen them with their testimony and by sharing their Christian experience with them. Days of recollection and retreats, which deepen the Christian dimension and meaning of this commitment, can also help young people in their immediate preparations for marriage.

\section{Giving consent}

Looking at the requirements of Western Christian tradition and at Gidar marriage, one might consider inserting these requirements into the $u k a$ stage, that is, the "transferal" of the girl to the boy's compound, as well as to the ute glo, the "setting up the hearth" stage. At these stages, African symbols may be introduced in place of wedding rings and only verbal marriage vows. This can be accompanied with the full wealth of formulas, prayers, and readings contained in the Roman Ritual. At this stage the spouses can be accompanied by a priest who represents the hierarchical Church, or if this is a difficulty his representative.

Certainly, a difficult problem to solve here is the need to pay the final installment of the matrimonial fee, as is the birth of a child stages of great importance in traditional marriage.

Some theologians, desiring to acknowledge the fullness of the stages in African traditions, no longer speak in their propositions of Christian "marriage in stages", but more subtly, distinguish "different degrees of sacramentality", recognizing the existence of a single sacramental reality. In their opinion, this is mandated by marital consent (consensus) which is increasingly being seen as an act of "becoming", and not a simple one-time action. Also, on the theological side, for the validity of marriage, consummation is required, not only an exchange of oaths, treated as a sacramental sign of marriage ${ }^{29}$.

Certainly, though, the Church, as an "expert on humanity", cannot destroy the symbolic dimension of marriage customs. This is not a question of preserving them simply as a form of folklore, as is the case with many liturgical adaptations.

${ }^{29}$ Ratum et consumatum. Cf. The Code of Canon Law, canon n. $1061-\S 1$. Code of Canon Law, Annotated. J. Bernhard, Le nouveau droit matrimonial, „Concilium” (1986) 205, p. 74. 
Such adaptations do not answer the problem that the Church faces when encountering custom-based marriage and culture.

\section{Summary}

In Cameroon we are dealing with three types of marriage: traditional, universally practiced marriage; civil marriage, required by state law before entering into a religious marriage; and, finally, sacramental marriage. Most widespread is the traditional form of contracting marriage. This article will present this particular form, referring to Gidar traditions and also showing its similarities to, and differences from, the Christian tradition brought by the missionaries. It will also propose solutions which combine the two traditions.

A characteristic feature of marriage rites was their multi-stage nature. They were not single acts but events long prepared and celebrated with suitable gestures, symbols, words, and events. The individual, successive stages of "taking a wife" consisted of the choice of a spouse, accepted by both families; an engagement period; an act by both families of acknowledgement of the joining of the young persons as one in marriage; the conveying of the bride to her husband's home; celebrating; and paying the matrimonial fee.

The Church in northern Cameroon recognized traditional marriages contracted outside of baptism as valid and licit, provided that local principles, e.g., payment of a marriage fee, were taken into account. If either of the parties accepted baptism, the marriage became for him or her sacramental. If the other party also made the same decision later on, their union took on a sacramental character, without a need to renew the marriage vows. Controversy would however arise if attempts were made to contract a traditional marriage if one party was [already] baptized, or if both parties were baptized. These controversies mainly concerned the unity, indissolubility, and sacramentality of marriage.

\section{Keywords}

northern Cameroon, Gidar, the traditional family, traditional African marriage, missions in Africa

\section{Zwyczajowe małżeństwo Gidarów a tradycja chrześcijańska}

\section{Streszczenie}

W Kamerunie mamy do czynienia z trzema rodzajami małżeństwa: małżeństwem zwyczajowym, praktykowanym powszechnie, małżeństwem cywilnym, wymaganym przez prawo państwowe przed zawarciem małżeństwa religijnego, wreszcie małżeństwem sakramentalnym. Najbardziej rozpowszechnione jest zawieranie małżeństwa w formie zwyczajowej. Niniejszy artykuł prezentuje tę właśnie formę, odwołując się do tradycji Gidar oraz wskazując na jej zbieżności i rozbieżności z przyniesioną przez misjonarzy tradycją chrześcijańską. Proponuje on także pewne rozwiązania łączące obydwie tradycje. 
Cechę charakterystyczną obrzędów małżeńskich stanowiła ich wieloetapowość. Nie były one jednorazowym aktem, lecz wydarzeniem przygotowywanym i celebrowanym dłużej przez odpowiednie gesty, symbole, słowa, wydarzenia. Na poszczególne, następujące po sobie etapy „wzięcia żony" składają się: wybór współmałżonka, zaakceptowany przez obydwa rody, próba narzeczonych, akt uznania przez obydwie grupy złączenia młodych w jedno małżeństwo, przeniesienie się narzeczonej do domu męża, świętowanie, uiszczenie opłaty matrymonialnej.

Kościół w północnym Kamerunie uznawał małżeństwo tradycyjne, zawarte przed chrztem, za ważne i godne, jeśli zostały uwzględnione miejscowe zasady związane np. z uregulowaniem opłaty matrymonialnej. Jeśli któraś strona przyjmowała chrzest, małżeństwo stawało się dla niej sakramentalne. Jeśli także druga strona podjęła później taką samą decyzję, ich związek nabierał charakteru sakramentalnego, bez ponawiania przysięgi małżeńskiej. Kontrowersje pojawiały się jednak przy próbach zawarcia związku tradycyjnego przez jedną stronę ochrzczoną lub też przez obydwie strony ochrzczone. Dotyczyły one głównie jedności, nierozerwalności oraz sakramentalności małżeństwa.

\section{Słowa kluczowe}

północny Kamerun, Gidar, tradycyjna rodzina, tradycyjne małżeństwo afrykańskie, misje w Afryce

\section{Bibliography}

Bernhard J., Le nouveau droit matrimonial, „Concilium” (1986) 205, pp. 67-106.

Bouba L., Mariage coutumier Guidar ou Kada et exigenes du mariage chrétien. Memoire de fin d'études de Grand Séminaire, [ms] Maroua 1991.

Bouchard J.C., La famille chrétienne dans le monde d'aujourd'hui. Compte-rendu du Synode des Évêques 1980 pour les communautés chrétiennes du Tchad, Moundou 1981.

Bujo B., Plea for change of models for marriage, Nairobi 2009.

Code of Canon Law, Annotated, eds. E. Caparros, M. Theriault, J. Thorn, Montreal 1993.

Collard C., Du bon ordre des enfants. Etude sur la germanité guidar, "Anthropologie et Société" 4 (1980) 2, pp. 39-64.

Collard C., La société guidar du Nord-Cameroun. Compte rendu de mission, "L'homme Revue Française d'Anthropologie" 11 (1971) 4, pp. 91-95.

Collard C., Les "noms-numéros” chez les Guidar, "L'homme - Revue Française d'Anthropologie" 13 (1973) 3, pp. 45-59.

Collard C., Organisation sociale des Guidar ou Baynawa (Cameroun septentrional), [mps] Paris-Nanterre 1977.

Draman O.L., Symbolisme religieux dans l'ethnie Ngambay. Approche culturelle de la religion, [ms] Ottawa 1975.

Әmanman Meleketeni. Nouveau Testament, guidar. Traduction, rédaction et révision linguistique: L. Bouba, T. Doulaneni, W. Kozioł, J. Maingle, M. Oumarou, J. Różański, K. Zielenda, Pelplin 2008. 
Enquete sur la coutume relative au mariage [in:] Rapport de stage de pastorale, Fort-Archambault, 20 juin-10 juillet 1971, Fort-Archambault 1971, pp. 44-50.

Frajzyngier Z., A Grammar of Gidar, Frankfurt am Main 2008.

John Paul II, Familiaris consortio, https://www.vatican.va/content/john-paul-ii/en/apost_ exhortations/documents/hf_jp-ii_exh_19811122_familiaris-consortio.html [accessed 10.20.2021].

John Paul II, Ecclesia in Africa, https://www.vatican.va/content/john-paul-ii/en/apost_ exhortations/documents/hf_jp-ii_exh_14091995_ecclesia-in-africa.html [accessed 10.10.2021].

Kisembo B., Magesa L., Shorter A., African Christian marriage, Nairobi 2015.

Kozioł W., Manglé J., Grammaire guidar, [ms] Figuil 1993.

Kurek, A., Wierzenia i obrzędy Gidarów, ludu pótnocnokameruńskiego. Studium historyczno-hermeneutyczne, Warszawa 1988.

Lestringant J., Le pays de Guider au Cameroun. Essai d'histoire régionale, Versailles [s.e.] 1964.

Maquet J., Mariage [in:] Balandier G., Maquet J., Alexandre P., Balfet H., Condominas G., et al., Dictionnaire des civilisations africaines, Paris 1968, pp. 263-264.

Mulago Gwa Cikala V., Mariage traditionnel africain et mariage chrétien, Kinshasa 1991. Philippe A., Le mariage. Droit canonique et coutumes africaines, Paris 1992.

Psaumes na Makada (gidar). Traduction, rédaction et révision linguistique: L. Bouba, T. Doulaneni, W. Kozioł, A. Madi, J. Maingle, B. Haman, M. Oumarou, J. Różański, K. Zielenda, Figuil-Varsovie 2015.

Różański J., W cieniu góry Lam, Gorzów Wielkopolski 1994.

Second Vatican Ecumenical Council, Pastoral Constitution on the Church in the Moderne World Gaudium et Spes, https://www.vatican.va/archive/hist_councils/ii_vatican_council/documents/vat-ii_const_19651207_gaudium-et-spes_en.html [accessed 09.10. 2021].

Symposium des Conférences épiscopales d'Afrique et de Madagascar, Justice, mariage et évangélisation en Afrique d'aujourd'hui, Yaoundé 1981, Accra 1982.

Symposium des Conférences épiscopales d'Afrique et de Madagascar, Vers l'indigénisation du rituel chrétien du mariage (Accra, 15 septembre 1976), "Documentation catholique" (1977) 1718, pp. 360-361.

Synodus episcoporum. Coetus specialis pro Africa, Les 64 propositions [in:] Le Synode aficaine. Histoire et textes, ed. M. Cheza, Paris 1996, pp. 239-268.

Szynkiewicz S., Ród [in:] Słownik etnologiczny, ed. Z. Staszczak, Warszawa-Poznań, p. 321.

Tagy M., Yondo A., Témoignage d'un foyer [in:] Rapport de stage de pastorale, Fort-Archambault, 20 juin-10 juillet 1971, Fort-Archambault 1971, pp. 59-64.

Wojtyła K., Miłość i odpowiedzialność, Lublin 1986.

Zielenda K., Prastare prawo lewiratu, „Misyjne Drogi” (1994) 3, pp. 14-15. 